\title{
Electrolyte oxidation pathways in lithium-ion batteries
}

\section{Supporting information}

Bernardine L. D. Rinkel, ${ }^{1}$ David S. Hall, ${ }^{1,2}$ Israel Temprano, ${ }^{1}$ Clare P. Grey ${ }^{1,2}$

${ }^{1}$ Department of Chemistry, University of Cambridge, Cambridge UK

${ }^{2}$ The Faraday Institution, Harwell UK 
1. H-cell setup used for the electrolysis of electrolyte solution.

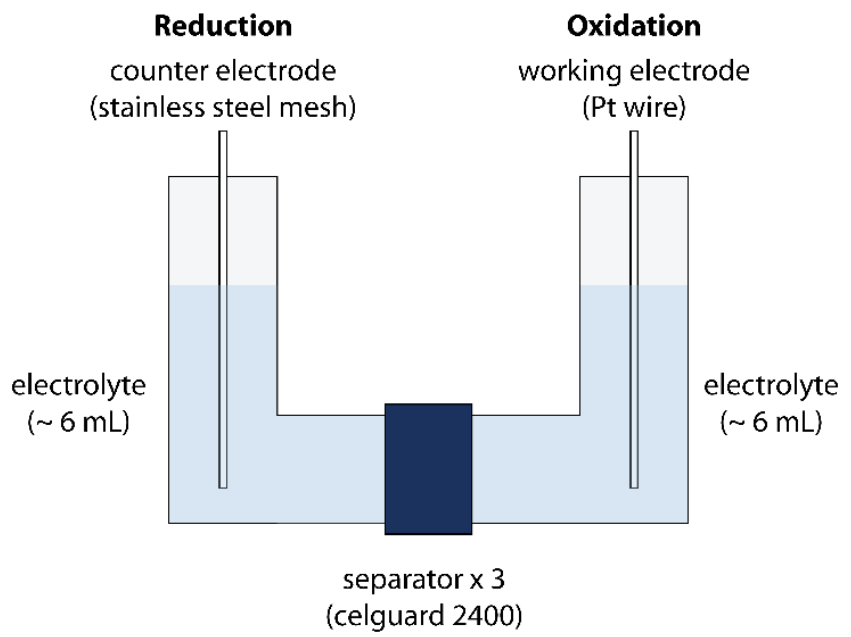

Figure S 1. A schematic of the H-cell set up used for the electrolysis of the electrolyte solution. 
2. Electrochemical data of the two-compartment $\mathrm{LiCoO}_{2} / \mathrm{Li}$ cells
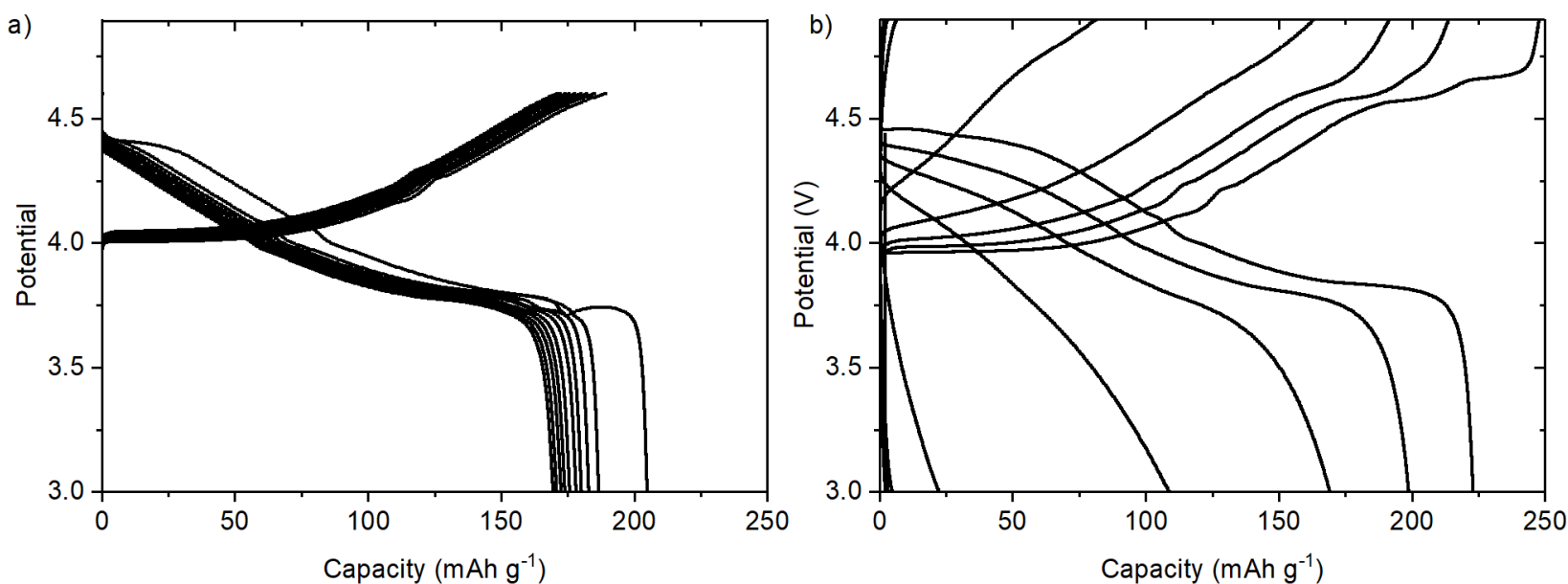

Figure S 2. Galvanostatic charge and discharge curves for $\mathrm{LiCOO}_{2} / \mathrm{Li}$ cells cycled at $\mathrm{C} / 5$ (based on the practical capacity of $\mathrm{LiCOO}_{2}=140 \mathrm{mAh} \mathrm{g}^{-1}$ ) between 3.0-4.6 V or 3.0-4.9 V (vs Li/Li+) for 10 cycles. 
3. Solution NMR

Table S 1. Summary of chemical shifts observed in the ${ }^{1} \mathrm{H},{ }^{19} \mathrm{~F}$ and ${ }^{31} \mathrm{P}$ solution NMR spectra in this work, and the conditions under which they are formed.

\begin{tabular}{|c|c|c|c|c|c|c|c|}
\hline \multirow[t]{2}{*}{ Electrode } & \multirow{2}{*}{$\begin{array}{l}\text { Cycling voltage } \\
\text { Limit }\end{array}$} & \multicolumn{2}{|c|}{${ }^{1} \mathrm{H}$ NMR spectrum } & \multicolumn{2}{|c|}{${ }^{19} \mathrm{~F}$ NMR spectrum } & \multicolumn{2}{|c|}{${ }^{31}$ P NMR spectrum } \\
\hline & & $\begin{array}{l}\text { Chemical shift } \\
\text { (ppm)* }\end{array}$ & $\begin{array}{l}\text { J-coupling } \\
\text { constant }(\mathrm{Hz})\end{array}$ & $\begin{array}{l}\text { Chemical shift } \\
\text { (ppm)* }\end{array}$ & $\begin{array}{l}\text { J-coupling } \\
\text { constant }(\mathrm{Hz})\end{array}$ & $\begin{array}{l}\text { Chemical shift } \\
(\text { ppm)* }\end{array}$ & $\begin{array}{l}\text { J-coupling } \\
\text { constant }(\mathrm{Hz})\end{array}$ \\
\hline Lithium metal & $4.6 \mathrm{~V}$ & $\begin{array}{l}4.29(\mathrm{~s}) \\
4.10(\mathrm{q}) \\
4.08(\mathrm{t}) \\
3.96(\mathrm{~d}) \\
3.55(\mathrm{t}) \\
3.33(\mathrm{~s}) \\
3.32(\mathrm{~s}) \\
3.24(\mathrm{~s}) \\
3.18(\mathrm{~d}) \\
2.70(\mathrm{~s}) \\
\end{array}$ & $\begin{array}{l}- \\
{ }^{3} J_{\mathrm{H}-\mathrm{H}}=5.5 \\
3 J_{\mathrm{H}-\mathrm{H}}=4.7 \\
1 J_{\mathrm{P}-\mathrm{H}}=10.0 \\
{ }^{3} \mathrm{~J}_{\mathrm{H}-\mathrm{H}}=4.7 \\
- \\
- \\
- \\
{ }^{3} \mathrm{~J}_{\mathrm{H}-\mathrm{H}}=5.5 \\
-\end{array}$ & $-83.1(d)$ & ${ }^{1} J_{P-F}=947$ & $-16.6(t)$ & $1 J_{P-F}=947$ \\
\hline Lithium metal & $4.9 \mathrm{~V}$ & \begin{tabular}{|l|}
$9.57(\mathrm{~s})$ \\
$8.14(\mathrm{~s})$ \\
$4.29(\mathrm{~s})$ \\
$4.10(\mathrm{q})$ \\
$4.08(\mathrm{t})$, \\
$3.96(\mathrm{~d})$ \\
$3.55(\mathrm{t})$ \\
$3.33(\mathrm{~s})$ \\
$3.32(\mathrm{~s})$ \\
$3.24(\mathrm{~s})$ \\
$3.18(\mathrm{~d})$ \\
$2.70(\mathrm{~s})$ \\
\end{tabular} & $\begin{array}{l}- \\
- \\
- \\
3 J_{\mathrm{H}-\mathrm{H}}=5.5 \\
3 \mathrm{~J}_{\mathrm{H}-\mathrm{H}}=4.7 \\
1 \mathrm{~J}_{\mathrm{P}-\mathrm{H}}=10.0 \\
3 \mathrm{~J}_{\mathrm{H}-\mathrm{H}}=4.7 \\
- \\
- \\
- \\
{ }^{3} \mathrm{~J}_{\mathrm{H}-\mathrm{H}}=5.5\end{array}$ & $\begin{array}{l}-83.1(\mathrm{~d}) \\
-135.2(\mathrm{~s}) \\
-138.8(\mathrm{~s}) \\
-152.7(\mathrm{~s})\end{array}$ & $\begin{array}{l}{ }^{1} J_{P-F}=947 \\
- \\
- \\
-\end{array}$ & $-16.6(t)$ & $1 J_{P-F}=947$ \\
\hline $\mathrm{LiCoO}_{2}$ & $4.6 \mathrm{~V}$ & \begin{tabular}{|l|}
$4.10(\mathrm{q})$ \\
$3.33(\mathrm{~s})$ \\
$3.32(\mathrm{~s})$ \\
$3.24(\mathrm{~s})$ \\
$3.18(\mathrm{~d})$ \\
\end{tabular} & $\begin{array}{l}{ }^{3} J_{\mathrm{H}-\mathrm{H}}=5.5 \\
- \\
- \\
- \\
{ }^{3} J_{\mathrm{H}-\mathrm{H}}=5.5\end{array}$ & - & - & - & - \\
\hline
\end{tabular}




\begin{tabular}{|c|c|c|c|c|c|c|c|}
\hline $\mathrm{LiCoO}_{2}$ & $4.9 \mathrm{~V}$ & $\begin{array}{l}10.6 \text { (broad) } \\
8.14(\mathrm{~s}) \\
4.10(\mathrm{q}) \\
3.99(\mathrm{~s}) \\
3.32(\mathrm{~s}) \\
3.24(\mathrm{~s}) \\
3.18(\mathrm{~d})\end{array}$ & $\begin{array}{l}- \\
- \\
{ }^{3} J_{H-H}=5.5 \\
- \\
- \\
- \\
{ }^{3} J_{H-H}=5.5\end{array}$ & $\begin{array}{l}-82.9(\mathrm{~d}) \\
-138.8(\mathrm{~s}) \\
-150.5(\mathrm{~s}) \\
-152.7(\mathrm{~s}) \\
-194.0(\mathrm{~s})\end{array}$ & $\begin{array}{l}{ }^{1} J_{P-F}=955 \\
- \\
- \\
- \\
-\end{array}$ & $-15.5(\mathrm{t})$ & ${ }^{1} J_{P-F}=955$ \\
\hline Platinum wire & Electrolysis & $\begin{array}{l}12.4 \text { (broad) } \\
9.61(\mathrm{~s}) \\
9.57(\mathrm{~s}) \\
7.71(\mathrm{~s}) \\
6.62(\mathrm{~m}) \\
6.55(\mathrm{ddd}) \\
\\
5.79(\mathrm{~s}) \\
5.70(\mathrm{~s}) \\
5.69(\mathrm{~s}) \\
4.73(\mathrm{ddd}) \\
\\
4.64(\mathrm{ddd}) \\
\\
3.99(\mathrm{~s})\end{array}$ & $\begin{array}{l}- \\
- \\
- \\
- \\
- \\
{ }^{2} J_{\mathrm{F}-\mathrm{H}}=60.7 \\
{ }^{3} J_{\mathrm{H}-\mathrm{H}}=4.1,0.7 \\
- \\
- \\
- \\
{ }^{2} J_{\mathrm{F}-\mathrm{H}}=36.3 \\
{ }^{3} J_{\mathrm{H}-\mathrm{H}}=11.0 \\
{ }^{2} \mathrm{~J}_{\mathrm{H}-\mathrm{H}}=4.2 \\
{ }^{2} J_{\mathrm{F}-\mathrm{H}}=21.3 \\
{ }^{3} \mathrm{~J}_{\mathrm{H}-\mathrm{H}}=11.0 \\
{ }^{2} \mathrm{~J}_{\mathrm{H}-\mathrm{H}}=0.7 \\
-\end{array}$ & $\begin{array}{l}-65.9(\mathrm{dd}) \\
-81.0(\mathrm{dt}) \\
-83.6 \mathrm{ppm}(\mathrm{d}) \\
-126.3(\mathrm{~s}) \\
-153.0(\mathrm{~s}) \\
-159.6(\mathrm{~s}) \\
-172.8(\mathrm{~s})\end{array}$ & $\begin{array}{l}{ }^{1} J_{\text {P-F }}=762 \\
{ }^{2} J_{\text {F-F }}=56 \\
{ }^{1} J_{\text {P-F }}=740 \\
{ }^{2} J_{\text {F-F }}=60 \\
{ }^{1} J_{\text {P-F }}=942 \\
- \\
- \\
- \\
-\end{array}$ & $-17.3(\mathrm{t})$ & ${ }^{1} J_{P-F}=942 \mathrm{~Hz}$ \\
\hline
\end{tabular}

*The multiplicity of the signal is given in parentheses after the chemical shift; $s=$ singlet, $d=$ doublet, $t=$ triplet, $q=$ quartet, $d d=$ doublet of doublets, ddd = doublet of doublet of doublets. 
The assignment of the signals is discussed per species in detail below and is based on complementary NMR experiments of the electrolyte samples measured in the present work, spectra measured from commercially provided reference compounds, and results reported in the published literature. The assignment of signals observed in multiple spectra will only be discussed in the first instance.

\section{$\underline{\text { Two-compartment LiCoO}} 2$-Li cells}

Reduction (Li metal)

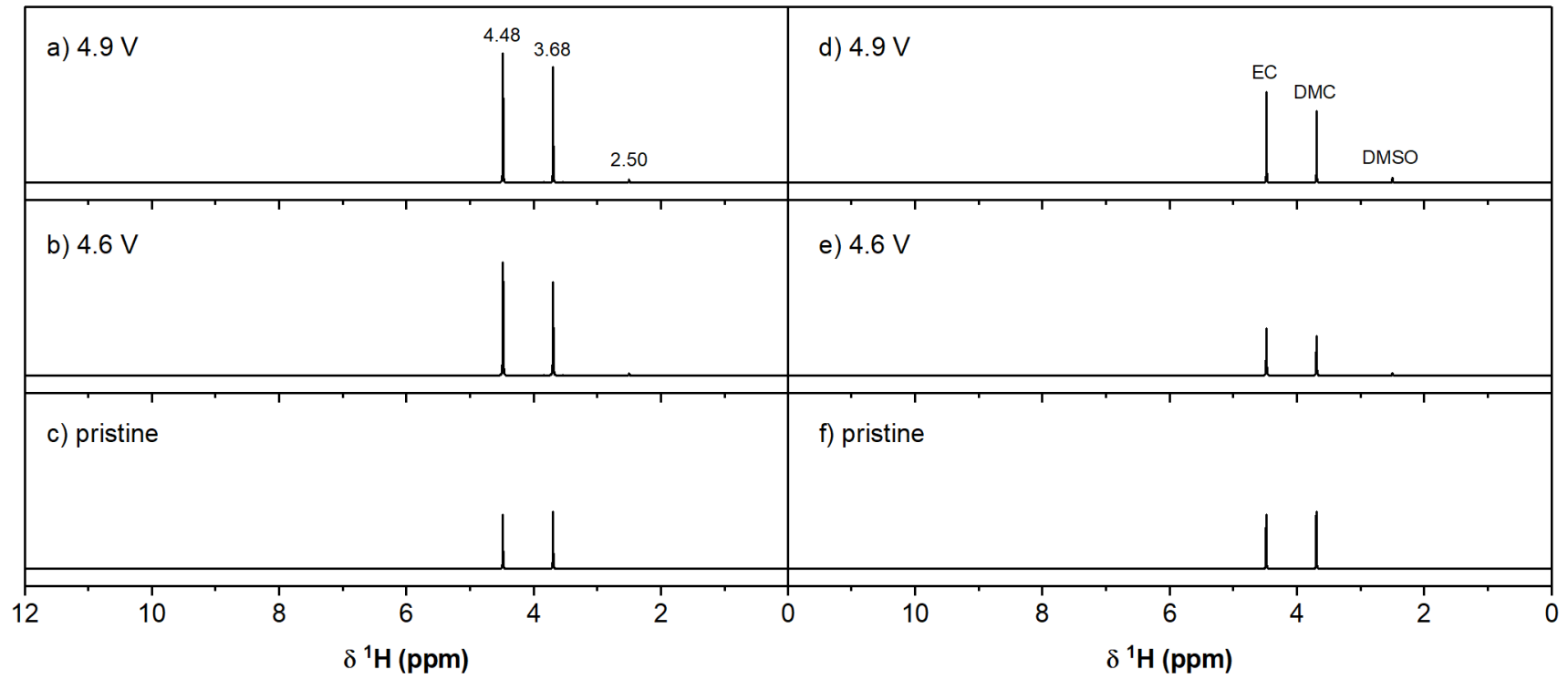

Figure S 3. Full ${ }^{1} \mathrm{H}$ solution NMR spectra of those shown in Figure 3 in the main text; ${ }^{1} \mathrm{H}$ solution NMR spectra of LP30 electrolyte extracted from the two-compartment $\mathrm{LiCOO}_{2} / \mathrm{Li}$ cells after 10 cycles between $3.0-4.9 \mathrm{~V}$ (top; a, d) and 3.0-4.6 V (middle; $b, e)$ and pristine electrolyte (bottom; $c, f)$. The spectra on the left are of electrolyte from the lithium metal side (a, b), the spectra on the right are of electrolyte from the $\mathrm{LiCOO}_{2}$ side of the cell $(d, e)$. The signal of ethylene carbonate (EC; 4.48 ppm), dimethyl carbonate (DMC; $3.68 \mathrm{ppm}$ ) and dimethyl sulfoxide (DMSO; $2.50 \mathrm{ppm}$ ) are annotated on the top spectra.

\section{${ }^{1}$ H NMR}

\section{Pristine electrolyte}

The assignments of the signals observed in the ${ }^{1} \mathrm{H}$ NMR spectrum of the pristine electrolyte in DMSO$d_{6}$ were all made based on the previously reported chemical shifts for ethylene carbonate (EC; 4.48 ppm), dimethyl carbonate (DMC; 3.68 ppm), ${ }^{1,2}$ non-deuterated DMSO (2.50 ppm), ${ }^{3} \mathrm{H}_{2} \mathrm{O}(3.33 \mathrm{ppm})^{3}$ and hydrofluoric acid (HF; $10.6 \mathrm{ppm}){ }^{4,5}$ The characteristic value of the ${ }^{1} J_{F-H}$ of the doublet $\left({ }^{1} J_{F-H}=410\right.$ $\mathrm{Hz}$ ) ascribed to $\mathrm{HF}$ further supported this assignment. 
Li metal side

The assignments of lithium ethylene dicarbonate (LEDC; $4.29 \mathrm{ppm})^{6}$ and lithium methyl carbonate (LMC; $3.24 \mathrm{ppm})^{7}$ were made based on previous literature.

\section{Methanol}

In the spectrum of the electrolyte from the lithium metal side from the cell cycled to $4.6 \mathrm{~V}$, (Figure 3c, main text) the quartet at 4.10 and doublet at $3.18 \mathrm{ppm}\left(\right.$ both $\left.{ }^{3}{ }_{\mathrm{H}-\mathrm{H}}=5.47 \mathrm{~Hz}\right)$ are assigned to the known positions of $\mathrm{OH}$ - and $\mathrm{CH}_{3}$-group of methanol, ${ }^{3}$ which is supported by a $2 \mathrm{D}{ }^{1} \mathrm{H}-{ }^{1} \mathrm{H}$ correlation spectroscopy (COSY) spectrum (Figure S 4). An off-diagonal peak (or cross peak) in a ${ }^{1} \mathrm{H}-{ }^{1} \mathrm{H}$ COSY NMR spectrum indicates coupling between protons that are usually three, or occasionally four bonds away. The ${ }^{1} \mathrm{H}-{ }^{1} \mathrm{H}$ COSY NMR spectrum of electrolyte from the lithium metal side of a $\mathrm{LiCoO}_{2} / \mathrm{Li}$ cell cycled to $4.6 \mathrm{~V}$ shows correlations between the proton signals at 4.10 and $3.18 \mathrm{ppm}$, indicating that the protons giving rise to these signals are chemically bonded. This combined with the multiplicity of the signals (quartet and doublet) supports the assignment of these signals to the $-\mathrm{OH}$ and $-\mathrm{CH}_{3}$ groups of methanol.

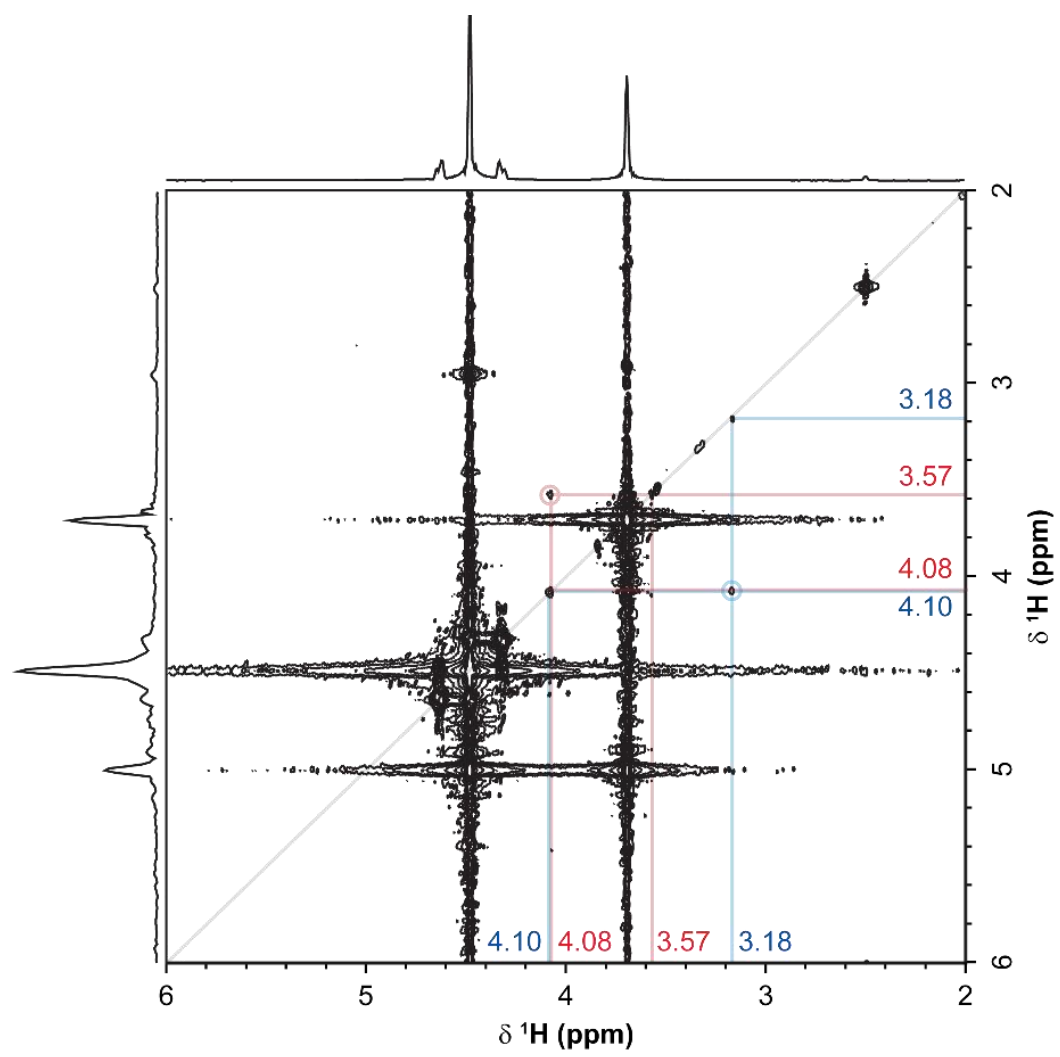

Figure S 4. ${ }^{1} \mathrm{H}-{ }^{1} \mathrm{H}$ COSY NMR spectrum of electrolyte extracted from the lithium metal side of a $\mathrm{LiCOO}_{2} / \mathrm{Li}$ cell cycled between 3.0-4.6 V for 10 cycles. Cross peaks are observed between the signals at 4.10 and 3.18 ppm and the signals at 4.08 and 3.57 ppm. 


\section{Lithium methoxide}

The singlet at $3.32 \mathrm{ppm}$ is assigned to lithium methoxide, on the basis of a close match with a reference spectrum (Figure 5 5).

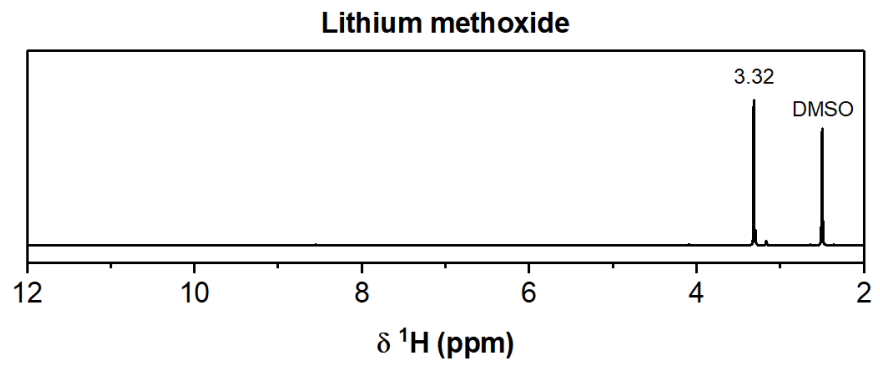

Figure S 5. ${ }^{1} \mathrm{H}$ NMR spectrum of lithium methoxide $\left(\mathrm{LiOCH}_{3}\right)$ in $\mathrm{DMSO}-\mathrm{d}_{6}$. The signal of the $-\mathrm{CH}_{3}$ group is observed at 3.32 ppm as a singlet.

Lithium ethylene monocarbonate (LEMC)

The triplets at 4.08 and $3.55 \mathrm{ppm}$ (both ${ }^{3} \mathrm{~J}_{\mathrm{H}-\mathrm{H}}=4.73 \mathrm{~Hz}$ ) are assigned to the two $\mathrm{CH}_{2}$-groups of lithium ethylene monocarbonate (LEMC), which is supported by a $2 \mathrm{D}{ }^{1} \mathrm{H}-{ }^{1} \mathrm{H}$ COSY spectrum showing a cross peak between these signals (Figure S 4). LEMC can form through the hydrolysis of EC, so a reference spectrum of LEMC was obtained by acquiring a $1 \mathrm{D}^{1} \mathrm{H}$ NMR spectrum (Figure $\mathrm{S} 6$ ) and a $2 \mathrm{D}^{1} \mathrm{H}-{ }^{1} \mathrm{H}$ COSY NMR spectrum (Figure S 7) of electrolyte solution that had been spiked with water. $1 \mathrm{~mL}$ of LP30 electrolyte $\left(1 \mathrm{M} \mathrm{LiPF}_{6}\right.$ in EC: DMC $\left.=50: 50 \mathrm{v} / \mathrm{v}\right)$ was spiked $0.1 \mathrm{~mL}$ of water $(=100,000 \mathrm{ppm})$ and stored for 2 months in a polypropylene container, after which $0.1 \mathrm{~mL}$ of electrolyte solution was taken for characterisation by NMR. The ${ }^{1} \mathrm{H}$ NMR spectrum of the electrolyte solution with 100,000 ppm water (Figure S 7) shows the appearance of two triplets at 4.08 and $3.57 \mathrm{ppm}\left({ }^{3} \mathrm{~J}_{\mathrm{H}-\mathrm{H}}=4.73 \mathrm{~Hz}\right.$ ) and the $2 \mathrm{D}^{1} \mathrm{H}-$ ${ }^{1} \mathrm{H}$ COSY NMR spectrum (Figure S 8 ) shows a correlation between these two signals. Based on the chemical shifts and the multiplicity of the signals (two triplets), a RO-C(=O)-O- $\mathrm{CH}_{2}-\mathrm{CH}_{2}-\mathrm{OR}$ fragment is proposed.

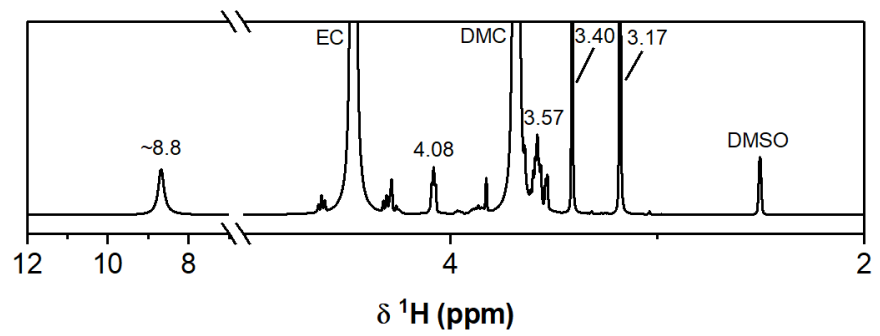

Figure S 6. ${ }^{1} \mathrm{H} N M R$ spectrum of $L P 30$ electrolyte $\left(1 \mathrm{M} \mathrm{LiPF}_{6}\right.$ in $\left.E C: D M C=50: 50 \mathrm{v} / \mathrm{v}\right)$ spiked with 100,000 ppm water, acquired two months after spiking the electrolyte with water. The main signals are assigned to EC (4.48 ppm), DMC (3.68 ppm). 


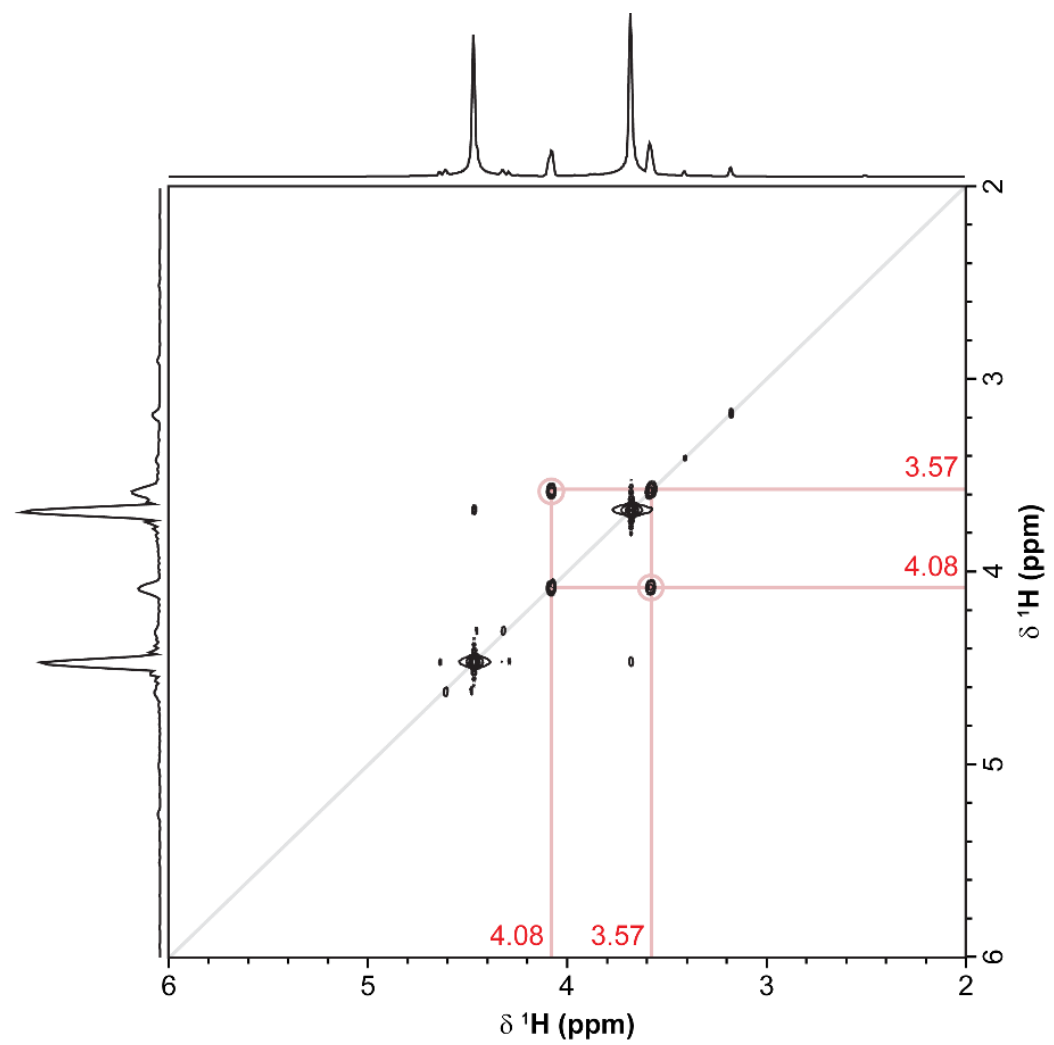

Figure S 7. ${ }^{1} \mathrm{H}-{ }^{1} \mathrm{H}$ COSY NMR spectrum of LP30 electrolyte (1 M LiPF 6 in EC:DMC $=50: 50 \mathrm{v} / \mathrm{v}$ ) spiked with 100,000 ppm water, acquired two months after spiking the electrolyte with water. A correlation between the signals at 4.08 and $3.57 \mathrm{ppm}$ is observed, which are assigned to the $-\mathrm{CH}_{2-}$ groups of lithium ethylene monocarbonate (LEMC).

Further evidence for this assignment of LEMC is provided by the ${ }^{1} \mathrm{H}-{ }^{13} \mathrm{C}$ heteronuclear single quantum coherence (HSQC) spectrum of the water-spiked electrolyte (Figure $S 8$ ), which shows two cross peaks between the ${ }^{1} \mathrm{H}$ NMR signals at 4.08 and $3.55 \mathrm{ppm}$ and ${ }^{13} \mathrm{C}$ NMR signals at 69.4 and $59.1 \mathrm{ppm}$, respectively, indicating that these proton nuclei are chemically bonded to those carbon nuclei. The chemical shifts of the ${ }^{13} \mathrm{C}$ signals match with previously reported ${ }^{13} \mathrm{C}$ shifts for ethylene monocarbonate salts. ${ }^{8}$ Therefore, the correlations are assigned to $\mathrm{LiO}-\mathrm{C}(=\mathrm{O})-\underline{\mathrm{CH}_{2}}-\mathrm{CH}_{2}-\mathrm{OH}\left(\delta^{1} \mathrm{H}=4.08, \delta^{13} \mathrm{C}=69.4 \mathrm{ppm}\right)$ and $\mathrm{LiO}-\mathrm{C}(=\mathrm{O})-\mathrm{CH}_{2}-\underline{\mathrm{CH}}_{2}-\mathrm{OH}\left(\delta{ }^{1} \mathrm{H}=3.57 \mathrm{ppm}, \delta{ }^{13} \mathrm{C}=59.1 \mathrm{ppm}\right)$ groups of lithium ethylene monocarbonate (LEMC). 


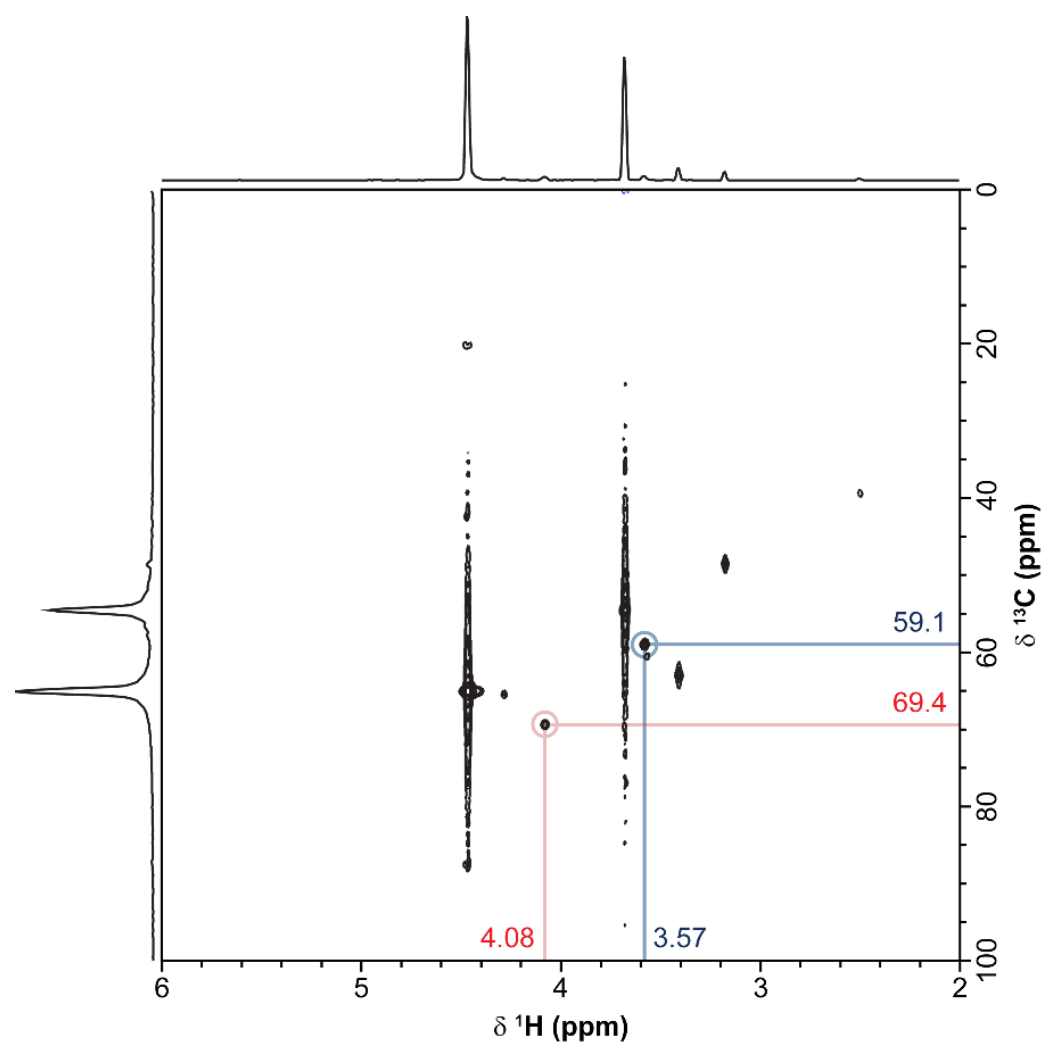

Figure S 8. ${ }^{1} \mathrm{H}_{-}{ }^{13} \mathrm{C}$ HSQC NMR spectrum of LP30 electrolyte (1 M LiPF 6 in EC:DMC =50:50 v/V) spiked with 100,000 ppm water, acquired two months after spiking the electrolyte with water.

\section{Lithium succinate}

The singlet at $2.70 \mathrm{ppm}$ falls in the chemical shift range for saturated aliphatic diketone, diesters and dicarboxylate, thus excluding molecules with a carbonate-functionality. The multiplicity of the signal indicates that this proton nucleus does not couple with other nuclei, which could either be due to this proton being the only proton nucleus in this molecule, this proton being too far away from other protons (or other NMR-active nuclei) to indirectly couple (J-couple), or the molecule being symmetrical. The simplest molecule with an alkyl carbon between two carbonyl groups, $\mathrm{RC}(=\mathrm{O})-\mathrm{C}_{2}{ }^{-}$ $\mathrm{C}(=\mathrm{O}) \mathrm{R}(\mathrm{R}=\mathrm{OH}$ for dicarboxylic acid, $\mathrm{R}=\mathrm{OR}$ for diester and $\mathrm{R}=$ alkyl group for diketone $)$, gives rise to a proton signal between $3.2-3.5 \mathrm{ppm}$, which is higher than the observed signal and therefore not considered. Increasing the alkyl carbon chain by one gives $\mathrm{RC}(=\mathrm{O})-\mathrm{CH}_{2}-\mathrm{C} \underline{H}_{2}-\mathrm{C}(=\mathrm{O}) \mathrm{R}$, which would still be consistent with the observed multiplicity and gives rise to a proton signal at $\sim 2.5 \mathrm{ppm}$ for diketones and $2.6-2.7$ for dicarboxylic acids and diesters. Any longer alkyl carbon chains would not be consistent with the observed multiplicity and are therefore not considered. Since no unassigned signals remain between $0-4 \mathrm{ppm}$, it is concluded that this species cannot contain additional saturated aliphatic groups, excluding diketones and diesters. Therefore, the signal at $2.70 \mathrm{ppm}$ is tentatively assigned to succinic acid or the lithium salt equivalent, which is supported by previously reported 
literature. ${ }^{9}$ Lithium succinate has previously been observed on the surface of cycled reduced graphene oxide electrodes. ${ }^{10}$

$\mathrm{OPF}_{2}\left(\mathrm{OCH}_{3}\right)$

The doublet at $3.96 \mathrm{ppm}\left({ }^{3} \mathrm{~J}_{\mathrm{P}-\mathrm{H}}=9.97 \mathrm{~Hz}\right)$ is assigned to a difluorophosphate ester species, $\mathrm{OPF}_{2}\left(\mathrm{OCH}_{3}\right)$. To confirm this assignment, the ${ }^{1} \mathrm{H}$ spectrum was recorded again with ${ }^{31} \mathrm{P}$ decoupling (Figure $\mathrm{S} 9$ ), which returned a singlet at $3.96 \mathrm{ppm}$. This indicates that the proton giving rise to this signal is coupled to a single phosphorus nucleus and the magnitude of the J-coupling further suggests that a three-bond coupling is most likely, such as in a P-O-C-H unit. The ${ }^{31} \mathrm{P}$ NMR spectrum of this sample (Figure S 10) reveals a triplet at $-16.6 \mathrm{ppm}\left({ }^{1} \mathrm{~J}_{\mathrm{F}-\mathrm{P}}=947 \mathrm{~Hz}\right)$, which is a characteristic ${ }^{1} \mathrm{~J}_{\mathrm{P}-\mathrm{F}}$ for tetracoordinated fluorophosphate esters, ${ }^{11}$ and the multiplicity of the signal indicates that the phosphorus nucleus is coupled to two equivalent fluorine nuclei, suggesting an $\mathrm{OPF}_{2}(\mathrm{OR})$ unit. Therefore, the combined results of the ${ }^{1} \mathrm{H},{ }^{1} \mathrm{H}\left\{{ }^{31} \mathrm{P}\right\}$, and ${ }^{31} \mathrm{P}$ NMR data support the assignment of the ${ }^{1} \mathrm{H}$ signal centred at 3.96 ppm to $\mathrm{OPF}_{2}\left(\mathrm{OCH}_{3}\right)^{2,12}$

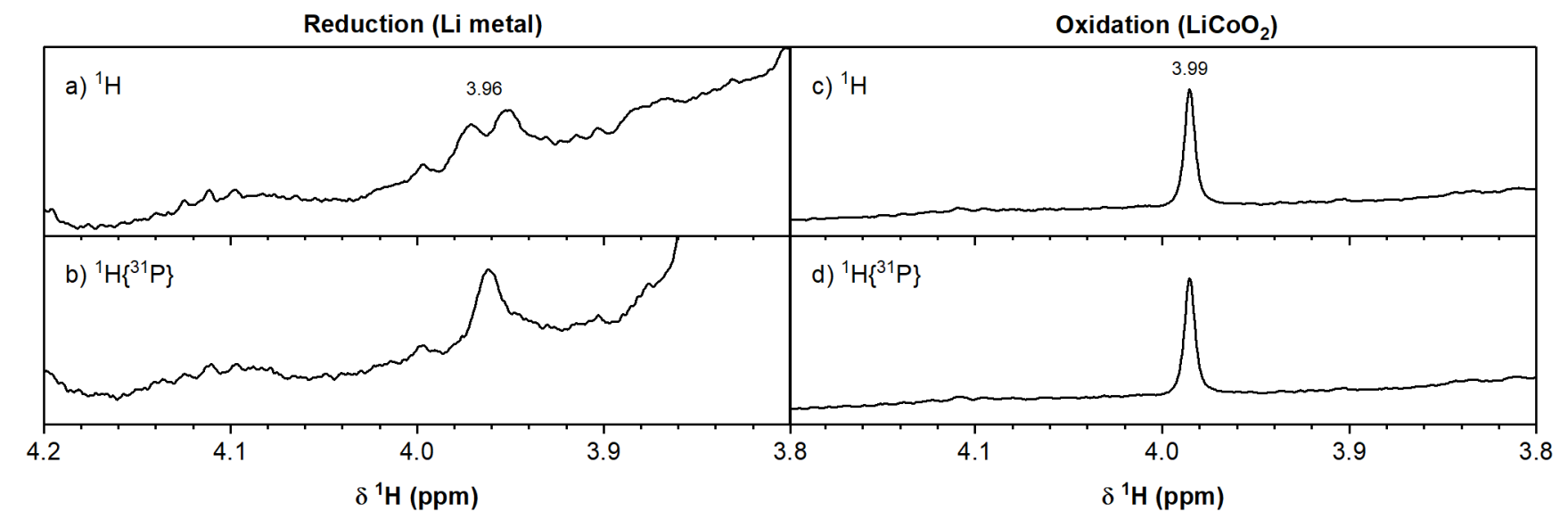

Figure S 9. Comparison of the ${ }^{1} H$ and ${ }^{1} H\left\{{ }^{31} P\right\} N M R$ spectra of electrolyte extracted from the $(a, b)$ lithium metal and $(c, d)$ $\mathrm{LiCOO}_{2}$ side of the $\mathrm{LiCOO}_{2} / \mathrm{Li}$ cell cycled between 3.0-4.9 V for 10 cycles. 


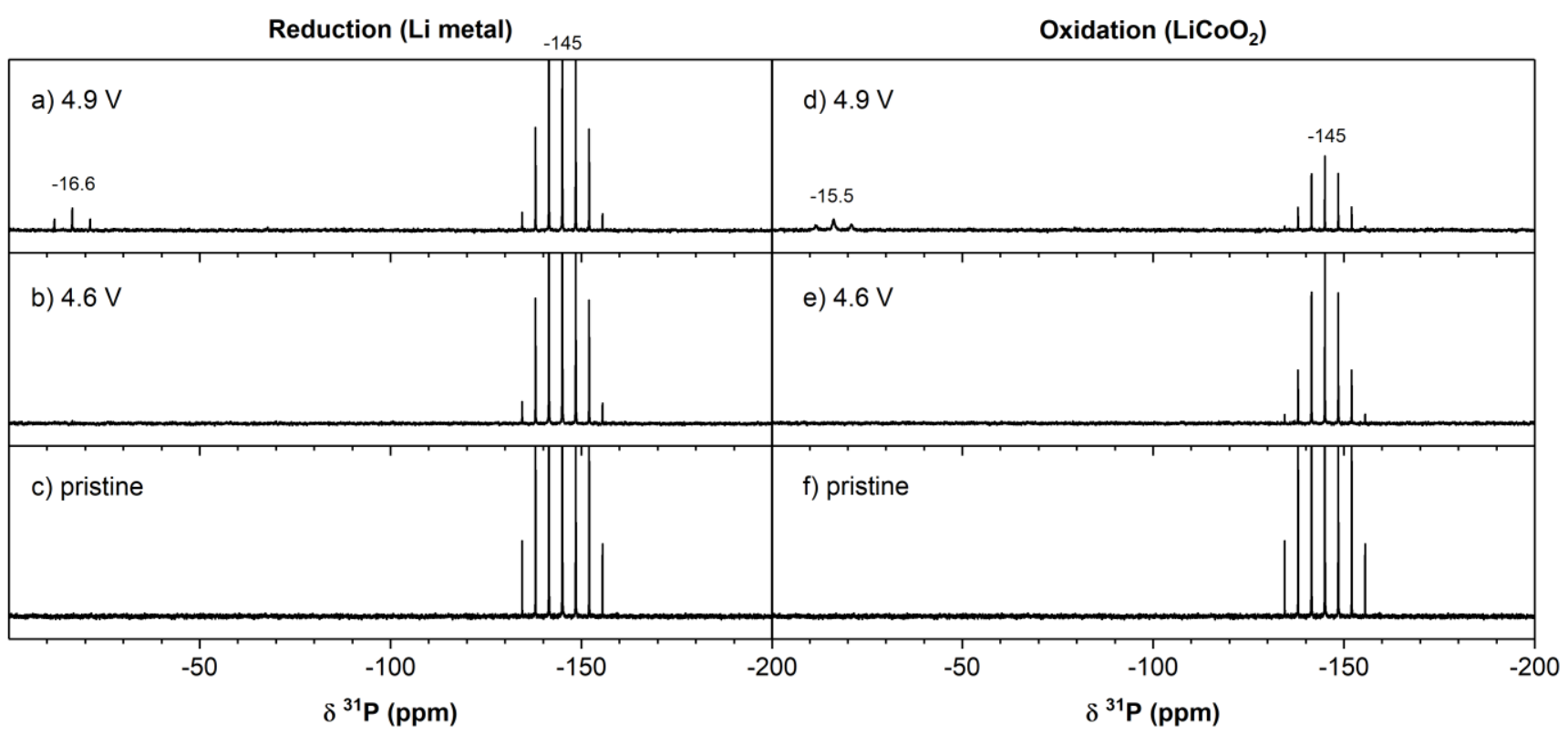

Figure S 10. ${ }^{31} \mathrm{P}$ solution NMR spectra of the electrolytes extracted from the two-compartment $\mathrm{LiCOO}_{2} / \mathrm{Li}$ cells after 10 cycles between 3.0-4.9 V (top; $a, d)$ and 3.0-4.6 V (middle; $b, e)$ and pristine electrolyte (bottom; $c, f)$. The spectra on the left are of electrolyte from the lithium metal side $(a, b)$, the spectra on the right are of electrolyte from the $\mathrm{LiCOO}_{2}$ side of the cell $(d, e)$. The chemical shifts of signals that appeared after electrochemical cycling are annotated on the spectra.

\section{$\underline{4.9 \mathrm{~V}}$}

$\mathrm{LiCoO}_{2}$ side

The assignment of the signal at $8.14 \mathrm{ppm}$ to formic acid was made based on previous reported chemical shifts. ${ }^{13}$ Figure $\mathrm{S} 11$ is an expansion between 14 and 8 ppm of the ${ }^{1} \mathrm{H}$ NMR spectrum (Figure 3 , main text) and shows the broad signal at $\sim 10.6 \mathrm{ppm}$. Based on the chemical shift, this signal is assigned to $\mathrm{HF}$ and protons in hydrogen bonded $\mathrm{H}(-\mathrm{FH})$ networks. The contribution of other hydrogenbonded protons on carboxylic acids and semi-carbonates is not excluded.

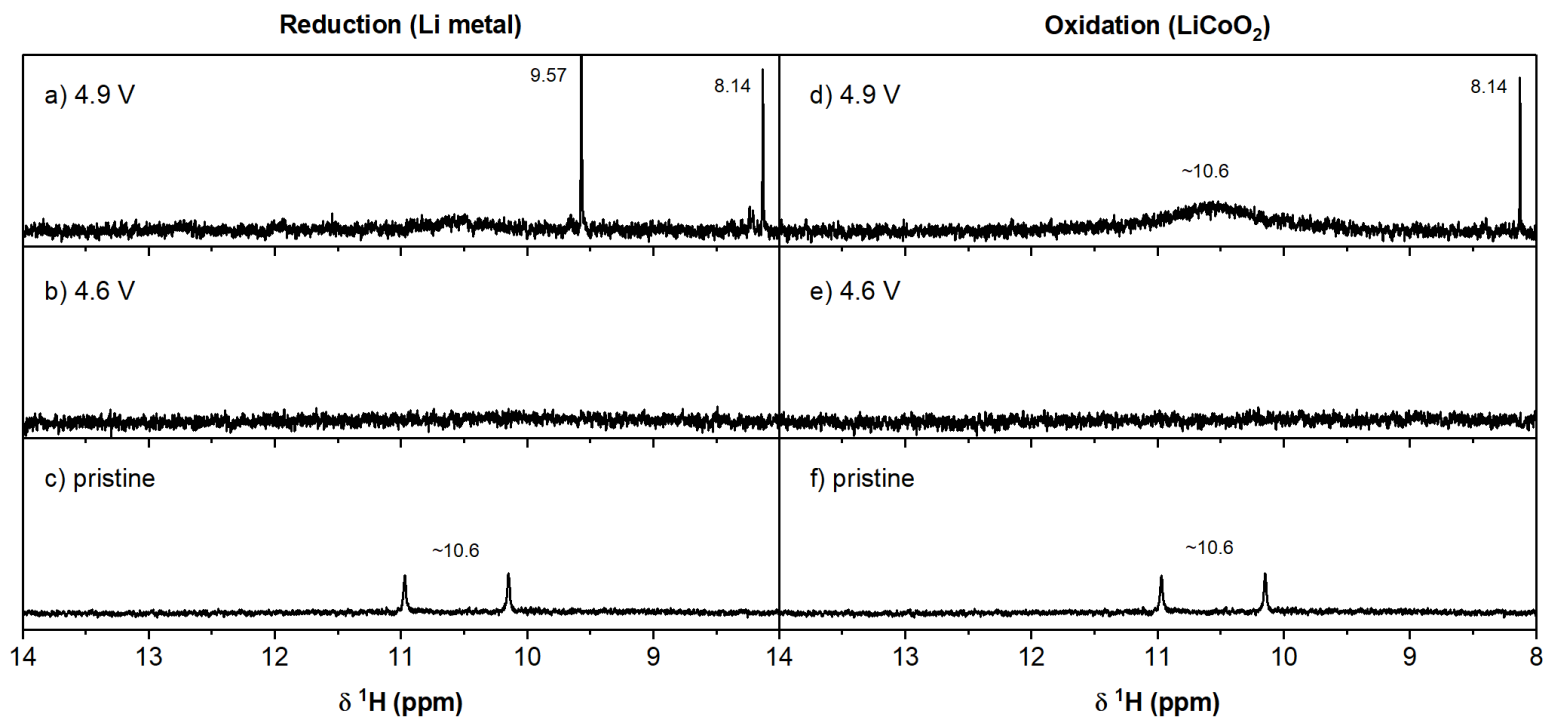

Figure S 11. Expansion of the region between 14 and 8 ppm of the ${ }^{1} H$ NMR spectrum shown in Figure 3. 


\section{Glycolic acid (or lithium glycolate)}

To identify the origin of the new signal at $3.99 \mathrm{ppm}$, a ${ }^{1} \mathrm{H}\left\{{ }^{31} \mathrm{P}\right\}$ (phosphorus-decoupled proton) spectrum was recorded, as the chemical shift is in the range of a fluorophosphate species and because both the ${ }^{19} \mathrm{~F}$ and ${ }^{31} \mathrm{P}$ NMR spectra show strong evidence for the presence of fluorophosphates. However, the ${ }^{1} \mathrm{H}\left\{{ }^{31} \mathrm{P}\right\}$ NMR spectrum (Figure S 9) showed no sharpening of the singlet at $3.99 \mathrm{ppm}$ and therefore this signal must not correspond to a fluorophosphate species. The chemical shift and the multiplicity of the signal (singlet) could also indicate a $\mathrm{HOC}(=\mathrm{O})-\mathrm{C}_{2}-\mathrm{OR}$ type species, and after considering possible decomposition pathways of EC (see discussion), the singlet at $3.99 \mathrm{ppm}$ is tentatively assigned to glycolic acid, $\mathrm{HOC}(=\mathrm{O})-\mathrm{CH}_{2}-\mathrm{OH}$, or lithium glycolate, $\mathrm{LiOC}(=\mathrm{O})-\mathrm{C}_{2}-\mathrm{OH}{ }^{14}$

Li metal side

The ${ }^{1} \mathrm{H}$ spectrum of the electrolyte from the lithium metal side of the cell cycled to $4.9 \mathrm{~V}$ (Figure $3 \mathrm{a}$, main text) shows two additional signals at $9.57 \mathrm{ppm}$ and $8.14 \mathrm{ppm}$ (lithium formate). ${ }^{13}$ The singlet at 9.57 falls in the chemical shift range for aldehydes, indicating a $\underline{H}-\mathrm{C}(=\mathrm{O})-\mathrm{R}$ structural unit. To satisfy the observed multiplicity (singlet), the molecule has to be either symmetrical, i.e., $\mathrm{R}=\mathrm{H}$ or $-\mathrm{C}(=\mathrm{O})-\mathrm{H}$, or no protons are close enough to indirectly couple, e.g., $\mathrm{R}=$ quaternary carbon. As no unassigned signals remain between $0-7 \mathrm{ppm}$, it is concluded that this molecule does not contain additional saturated or unsaturated carbons. Therefore, the molecule is presumed to be symmetrical, leaving only two options, formaldehyde $(R=H)$ and glyoxal $(R=-C(=O)-H$; ethanedial). By this logic and following comparison with chemical shifts reported in the literature, ${ }^{15}$ the singlet at $9.57 \mathrm{ppm}$ is assigned to formaldehyde.

\section{${ }^{19}$ F NMR}

\section{Pristine electrolyte}

The ${ }^{19} \mathrm{~F}\left\{{ }^{1} \mathrm{H}\right\}$ spectrum measured from the pristine electrolyte (Figure $4 \mathrm{c}$ and $\mathrm{f}$ main text) shows a major signal at $-74.5 \mathrm{ppm}$ and is assigned to $\operatorname{LiPF}_{6}\left(-74.5 \mathrm{ppm}, \mathrm{d},{ }^{1} \mathrm{JPF}_{\mathrm{F}}=710 \mathrm{~Hz}\right)$, supported by its multiplicity (doublet) and the presence of a corresponding septet $\left({ }^{1} J_{F-P}=710 \mathrm{~Hz}\right)$ at $-145.0 \mathrm{ppm}$ in the ${ }^{31} \mathrm{P}$ NMR spectrum (Figure S 10). ${ }^{1,2}$ Minor signals are assigned to $\mathrm{LiPO}_{2} \mathrm{~F}_{2}\left(-82.9 \mathrm{ppm}, \mathrm{d},{ }^{1} \mathrm{JPF}_{\mathrm{F}}=955 \mathrm{~Hz}\right.$ ), and HF $\left(-171.6 \mathrm{ppm}\right.$ ) impurities. ${ }^{2,4,5}$ (For the latter, a singlet is expected because the spectra were collected using proton decoupling.) 
$\mathrm{LiCoO}_{2}$ side

The assignments of silicon fluorides $\left(\mathrm{SiF}_{\mathrm{x}} \mathrm{x}=4-6 ;-138.8 \mathrm{ppm}\right)^{16}$ and $\mathrm{HF}(-194.0 \mathrm{ppm})^{4,5}$ were made based on previous literature.

$\mathrm{OPF}_{2}(\mathrm{OH}) / \mathrm{PO}_{2} \mathrm{~F}_{2}^{-}$

The doublet at $-82.9 \mathrm{ppm}\left(\mathrm{d},{ }^{1}{ }_{\mathrm{P}-\mathrm{F}}=955 \mathrm{~Hz}\right.$ ) is assigned to difluorophosphoric acid, $\mathrm{OPF}_{2}(\mathrm{OH})$ or its conjugate base, $\mathrm{PO}_{2} \mathrm{~F}_{2}$, based on the ${ }^{1} \mathrm{~J}_{\mathrm{F}-\mathrm{P}}$ coupling constant and the triplet observed at $-15.5 \mathrm{ppm}$ $\left({ }^{1} J_{F-P}=955 \mathrm{~Hz}\right)$ in the ${ }^{31} \mathrm{P}$ NMR spectrum (Figure S 10)..$^{2,12,17}$

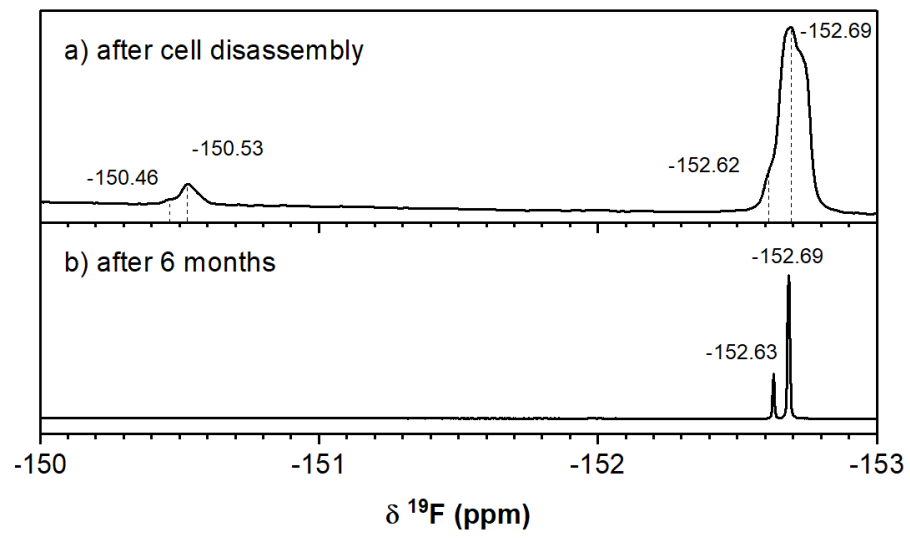

Figure S 12. Expansion of the region between -150 and $-153 \mathrm{ppm}$ of the ${ }^{19} \mathrm{~F}$ NMR spectrum shown in Figure 4.

Lithium fluoroborate $\left(\mathrm{LiBF}_{4}\right)$ and $\mathrm{OPF}_{2}(\mathrm{OH})-\mathrm{BF}_{3}$

On closer inspection (see Figure S 12 for the expanded spectrum), the signals at $-152.7\left(\mathrm{LiBF}_{4}\right)$ and 150.5 ppm appear as two signals in a 1:4 ratio, which corresponds to the abundance ratio of the two naturally occurring boron isotopes $\left(20 \%{ }^{10} \mathrm{~B}\right.$ and $\left.80 \%{ }^{11} \mathrm{~B}\right) .{ }^{12}$ Previously observed fluoroborate species in electrolytes include $\mathrm{LiBF}_{4}$ and $\mathrm{OPF}_{2}(\mathrm{OH})-\mathrm{BF}_{3}$. Chemically related electrolyte additives were also considered, especially lithium difluorooxalatoborate (LiDFOB). A reference spectrum was measured for LiDFOB, however its chemical shift of -155.1 ppm (Figure S 13) is not a good match for either of the peaks here observed. The signal at $-152.7 \mathrm{ppm}$ is assigned to $\mathrm{LiBF}_{4}$, on the basis of a close match with a reference spectrum (Figure S 14$).{ }^{17}$

On the basis of its chemical shift, the signal at $-150.5 \mathrm{ppm}$ could arise from $\mathrm{OPF}_{2}(\mathrm{OH})-\mathrm{BF}_{3}$, as suggested by Winter and co-workers. ${ }^{12}$ 


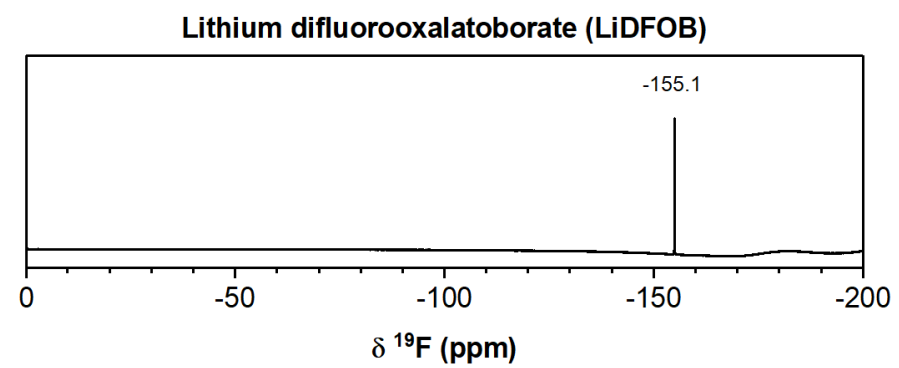

Figure S 13. ${ }^{19} \mathrm{~F}$ NMR spectrum of lithium difluorooxalatoborate (LiDFOB) in DMSO-d $d_{6}$; the 19F NMR signal is observed at $155.5 \mathrm{ppm}$.

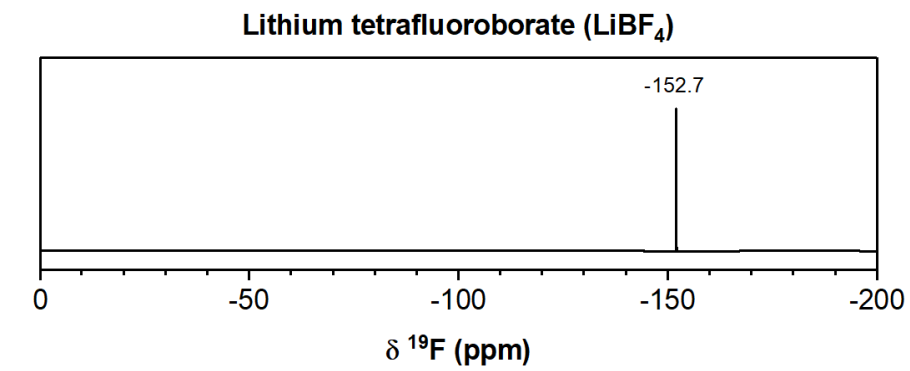

Figure S 14. ${ }^{19} \mathrm{~F} N M R$ spectrum of lithium tetrafluoroborate $\left(L_{i B F_{4}}\right)$ in DMSO-d $d_{6}$; the 19F NMR signal is observed at -152.7 ppm.

\section{Electrolytes from the electrolytic $\mathrm{H}$-cell experiments}

\section{${ }^{1} \mathrm{H}$ NMR}

To understand from which carbonate (EC or DMC) the observed decomposition products originated, the experiment was repeated using an electrolyte without EC (i.e. $1 \mathrm{M} \mathrm{LiPF}_{6}$ in $\mathrm{DMC}$ ), the signals corresponding to the electrolyte decomposition products originating from EC and DMC can be distinguished (Figure S 15). 


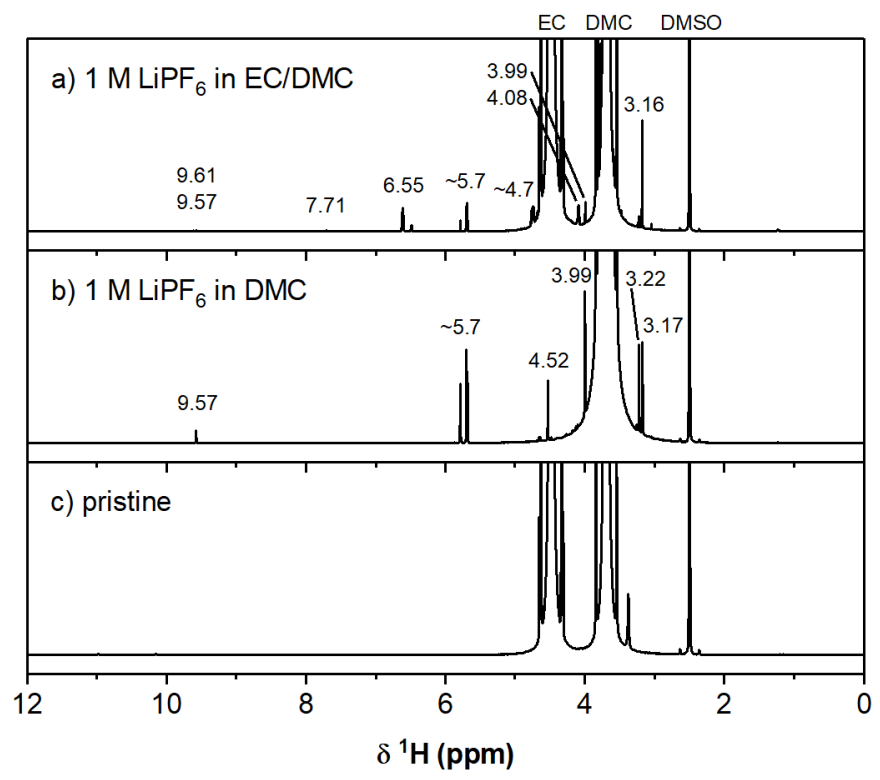

Figure S 15. ${ }^{1} \mathrm{H}$ NMR spectra of electrolyte extracted from the oxidation side of a conventional 2-compartment $\mathrm{H}$-cell after

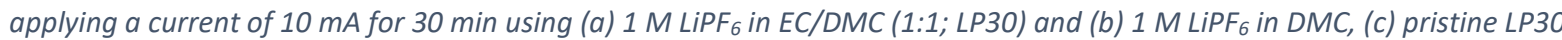
electrolyte. The main signals correspond to EC (4.48 ppm), DMC (3.68 ppm) and DMSO (2.50 ppm). The chemical shifts of the signals that appeared after electrolysis are annotated on the spectra.

The signal at $7.71 \mathrm{ppm}(\mathrm{s})$ is assigned to vinylene carbonate (VC), based on its previously reported chemical shift. ${ }^{18}$ The signal at $9.61 \mathrm{ppm}$ is assigned to a small symmetrical molecule with an aldehydefunctionality, such as glyoxal, $\underline{\boldsymbol{H}}-\mathrm{C}(=\mathrm{O})-\mathrm{C}(=\mathbf{O})-\underline{\boldsymbol{H}}(9.61 \mathrm{ppm})$ following a similar logic as was discussed for the signal at $9.57 \mathrm{ppm}$.

\section{Fluoroethylene carbonate (FEC)}

The signal at $6.55\left(\mathrm{dd},{ }^{2} \mathrm{~J}_{\mathrm{F}-\mathrm{H}}=60.70 \mathrm{~Hz},{ }^{3} J_{\mathrm{H}-\mathrm{H}}=4.13 \mathrm{~Hz}\right)$ and the signals between 4.6-4.8 ppm (4.73; ddd, ${ }^{2} J_{\mathrm{F}-\mathrm{H}}=36.3 \mathrm{~Hz},{ }^{3} J_{\mathrm{H}-\mathrm{H}}=11.0,4.17 \mathrm{~Hz}$ and $4.64 ; \mathrm{ddd},{ }^{2} \mathrm{~J}_{\mathrm{F}-\mathrm{H}}=21.3 \mathrm{~Hz},{ }^{3} J_{\mathrm{H}-\mathrm{H}}=11.0,0.69 \mathrm{~Hz}$ ) are assigned to fluoroethylene carbonate (FEC), after comparison with a ${ }^{1} \mathrm{H}$ NMR spectrum of FEC in DMSO- $d_{6}$ (Figure S 16).

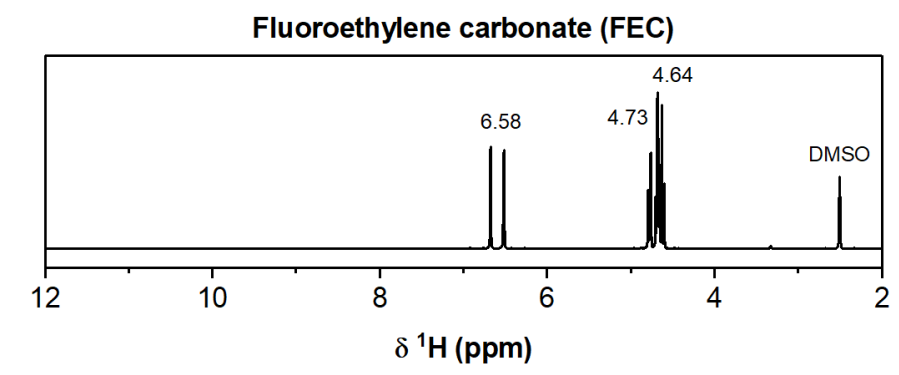

Figure S 16. ${ }^{1} \mathrm{H} N M R$ spectrum of fluoroethylene carbonate (FEC) in DMSO-d $d_{6} ;$ the ${ }^{1} \mathrm{H} N M R$ signals are observed at $6.58 \mathrm{ppm}$ $\left(d d d,{ }^{3} J_{F^{-H}}=60.7 \mathrm{~Hz},{ }^{3} \mathrm{~J}_{\mathrm{H}^{-H}}=4.13,0.67 \mathrm{~Hz}\right), 4.73 \mathrm{ppm}\left(d d d,{ }^{2} J_{F_{-H}}=36.3 \mathrm{~Hz},{ }^{3} \mathrm{~J}_{\mathrm{H}-\mathrm{H}}=11.0,4.17 \mathrm{~Hz}\right)$ and $4.64 \mathrm{ppm}(\mathrm{ddd}$, $\left.{ }^{2} J_{F-H}=21.3 p p m,{ }^{3} J_{H-H}=11.0,0.69 \mathrm{~Hz}\right)$. 
Reduction (Li metal)

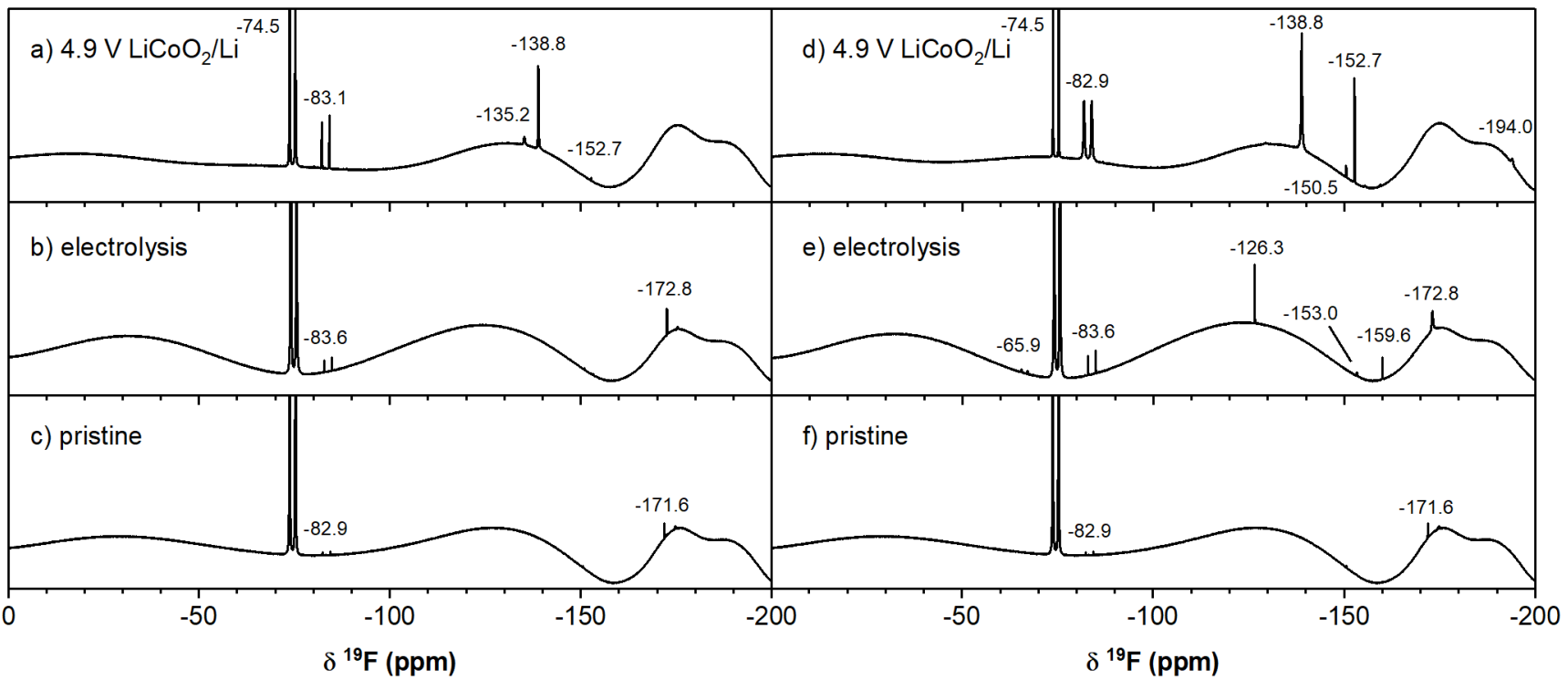

Figure S 17. ${ }^{19} \mathrm{~F}$ solution NMR spectra of LP30 electrolyte extracted from the two-compartment LiCoO $/$ Li cells after 10 cycles between 3.0-4.9 V (top; $a, d)$ and the conventional 2-compartment electrolysis $\mathrm{H}$-cell after applying a current of $10 \mathrm{~mA}$ for $30 \mathrm{~min}$ (middle; $b, e$ ) and pristine electrolyte (bottom; $c$, f). The chemical shifts of the observed signals are annotated on the spectra.

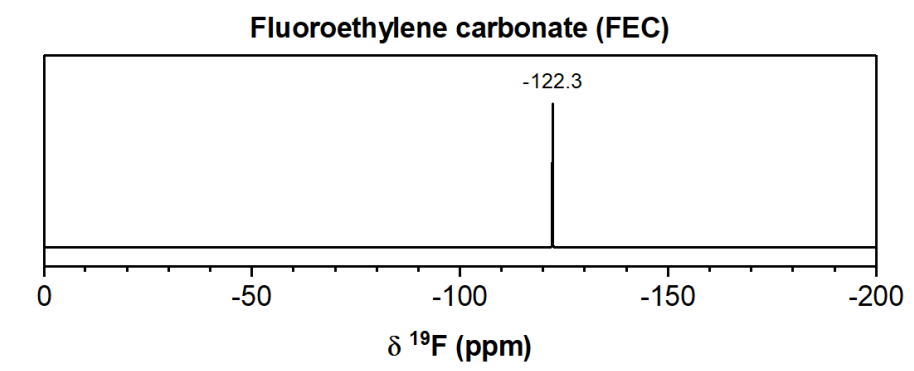

Figure S 18. ${ }^{19} \mathrm{~F}$ NMR spectrum of fluoroethylene carbonate (FEC) in DMSO- $d_{6}$; the ${ }^{19} \mathrm{~F}$ NMR signal is observed at -122.3 ppm.

Further evidence for the presence of FEC is provided by the presence of a signal at $-126.3 \mathrm{ppm}$ in the ${ }^{19} \mathrm{~F}$ NMR spectrum of the oxidise electrolyte (Figure $\mathrm{S} 17$ ), which was supported by ${ }^{19} \mathrm{~F}$ NMR measurement of FEC (Figure S 18).

\section{${ }^{19}$ F NMR}

\section{Trifluorooxalatophosphate $\left(\mathrm{PF}_{3} \mathrm{C}_{2} \mathrm{O}_{4}\right)$}

The multiplets at $-65.9 \mathrm{ppm}\left(\mathrm{dd},{ }^{1} J_{\mathrm{P}-\mathrm{F}}=762 \mathrm{~Hz},{ }^{2} \mathrm{~J}_{\mathrm{F}-\mathrm{F}}=56 \mathrm{~Hz}\right),-81.0 \mathrm{ppm}\left(\mathrm{dt},{ }^{1} J_{\mathrm{P}-\mathrm{F}}=740 \mathrm{~Hz},{ }^{2} \mathrm{~J}_{\mathrm{F}-\mathrm{F}}=60 \mathrm{~Hz}\right)$ have a ${ }^{1} J_{\text {P-F }}$ value characteristic for hexacoordinated fluorophosphates $(\sim 700 \mathrm{~Hz})$ or of axial fluorinephosphorus coupling in pentacoordinate fluorophosphates $(\sim 800 \mathrm{~Hz}) .{ }^{11}$ The multiplicity of the signals indicates two inequivalent fluorine environments with two fluorine nuclei giving rise to the doublets at $-65.9 \mathrm{ppm}$ and one fluorine nucleus giving rise to triplets at $-81.0 \mathrm{ppm}$. This would suggest a 
pentacoordinate fluorophosphate species with a trigonal bipyramidal geometry where two of the fluorine atoms are in equatorial positions and the remaining fluorine atom is in an axial position. Since the two fluorine environments can clearly be distinguished, there is no exchange between the axial and equatorial ligands (Berry pseudo rotation) at room temperature, which is common for molecules with a trigonal bipyramidal geometry. Bidentate ligands, such as an oxalate ligand, can prevent this isomerisation, therefore the signals at -65.9 and $-81.0 \mathrm{ppm}$ are assigned to the equatorial and axial fluorine nuclei in trifluorooxalatophosphate $\left(\mathrm{PF}_{3} \mathrm{C}_{2} \mathrm{O}_{4}\right)$. It is noteworthy that Lucht and co-workers have previously synthesized the related salt lithium tetrafluorooxalatophosphate, $\operatorname{LiPF}_{4}\left(C_{2} \mathrm{O}_{4}\right)$, as an electrolyte additive. ${ }^{19}$ Furthermore, the presence of insoluble lithium oxalate has been reported at the surface of cathode materials.

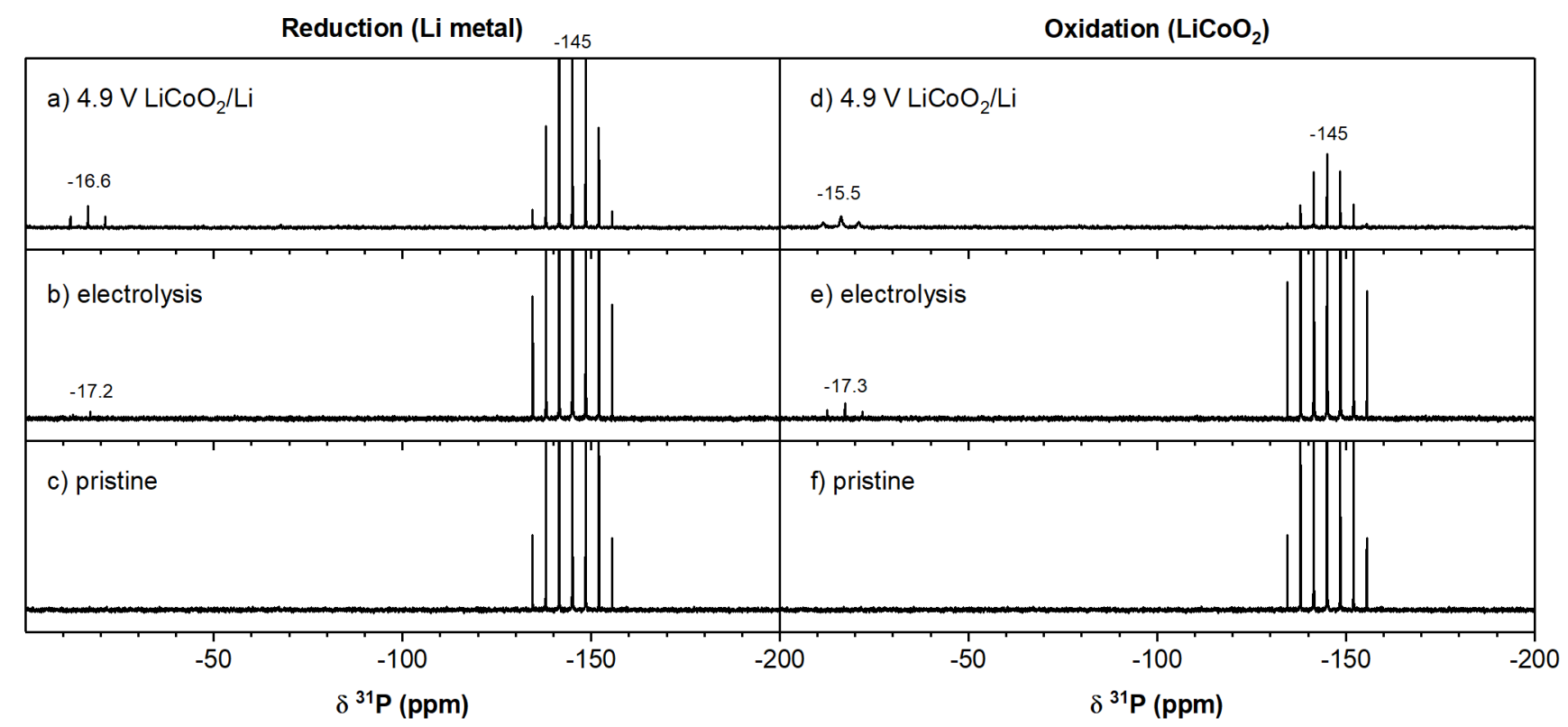

Figure S 19. ${ }^{31} \mathrm{P}$ solution NMR spectra of LP30 electrolyte extracted from the two-compartment LiCoO $/$ Li cells after 10 cycles between $3.0-4.9 \mathrm{~V}($ top; $a, d)$ and the conventional 2-compartment electrolysis $\mathrm{H}$-cell after applying a current of $10 \mathrm{~mA}$ for $30 \mathrm{~min}$ (middle; $b, e$ ) and pristine electrolyte (bottom; $c, f$ ). The chemical shifts of the observed signals are annotated on the spectra.

The main products formed through electrochemical oxidation of the electrolyte in a conventional twocompartment $\mathrm{H}$-cell were identified as FEC and VC, originating from EC decomposition, and formaldehyde and various acetal species, resulting from DMC oxidation. The formation of VC at the positive electrode has been ascribed to the dehydrogenation of EC at the surface of transition metal oxide particles. ${ }^{61}$ It is unclear whether FEC forms directly through oxidation at the positive electrode or if it results from further reactions of VC with other fluorinated species in the electrolyte. The formation of formaldehyde is also poorly understood, but formaldehyde is highly susceptible to nucleophilic attack from alcohols or water, resulting in the formation of the observed acetal species methanediol $\left(\mathrm{CH}_{2}(\mathrm{OH})_{2}\right)$ and methoxymethanol $\left(\mathrm{CH}_{2}\left(\mathrm{OCH}_{3}\right)(\mathrm{OH})\right)$. 


\section{Electrolyte hydrolysis}

To understand what decomposition form through hydrolysis, $1 \mathrm{~mL}$ of LP30 electrolyte (1 M LiPF 6 in EC: DMC $=50: 50 \mathrm{v} / \mathrm{v})$ was spiked $0.1 \mathrm{~mL}$ of water $(=100,000 \mathrm{ppm})$ and stored for 2 months in a polypropylene container. The ${ }^{1} \mathrm{H}$ NMR spectrum (Figure S2O a) of the electrolyte shows signals for lithium ethylene monocarbonate (LEMC; $4.08 \mathrm{ppm}, \mathrm{t},{ }^{3} \int_{\mathrm{H}-\mathrm{H}}=4.73 \mathrm{~Hz} ; 3.57 \mathrm{ppm}, \mathrm{t},{ }^{3} \mathrm{H}_{\mathrm{H}-\mathrm{H}}=4.73 \mathrm{~Hz}$ ), ethylene glycol (EG; 3.40 ppm, s), methanol $(3.17, \mathrm{~s})$ and broad signal for hydrofluoric acid (HF; 8.8 ppm).

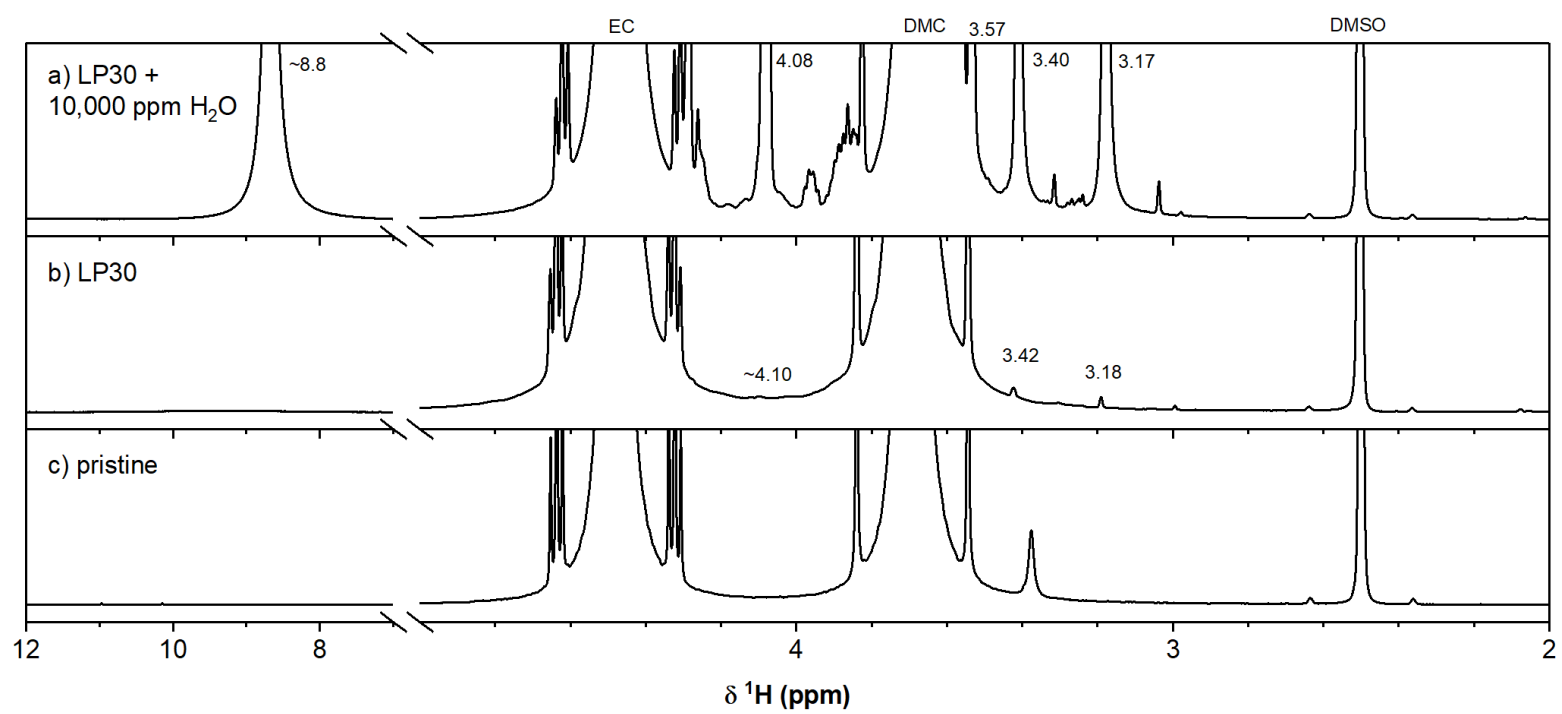

Figure S 20. ${ }^{1} \mathrm{H}$ NMR spectrum of electrolyte (a) with 100,000 ppm water and (b) without stored for 2 months in an air-tight polypropylene container and (c) pristine electrolyte.

A control electrolyte was stored under the same conditions and its ${ }^{1} \mathrm{H}$ NMR spectrum is shown in Figure S20 b. Signals for methanol (4.10 and 3.18 ppm) and EG (3.42 ppm) are observed, indicating that hydrolysis of DMC and EC by trace moisture does occur, but at very slow rates. 
Figure S 21. Overview of electrolyte decomposition reactions discussed in this work.

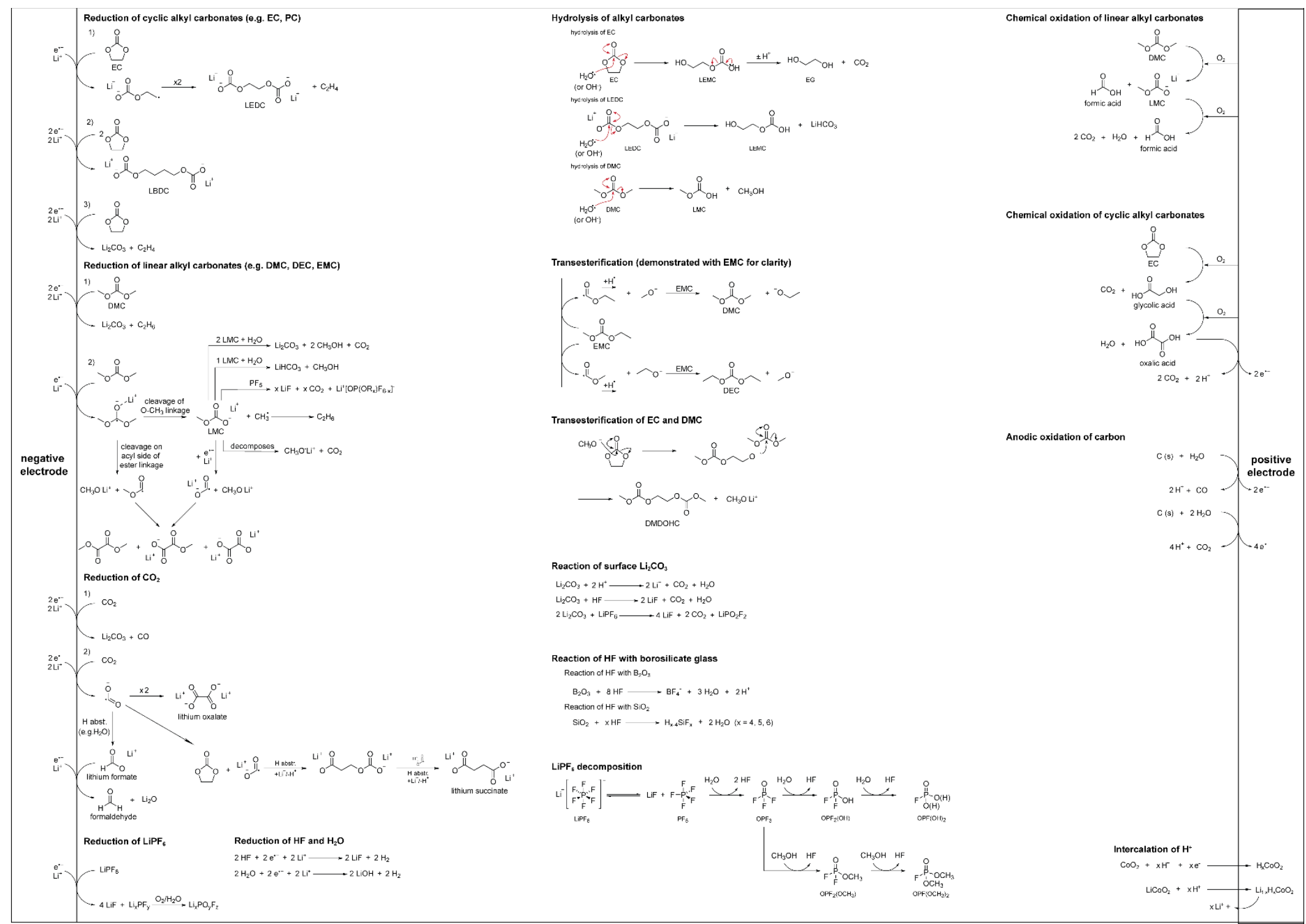




\section{References}

(1) Ravdel, B.; Abraham, K. M.; Gitzendanner, R.; DiCarlo, J.; Lucht, B.; Campion, C. Thermal Stability of Lithium-Ion Battery Electrolytes. J. Power Sources 2003, 119-121, 805-810. https://doi.org/10.1016/S0378-7753(03)00257-X.

(2) Campion, C. L.; Li, W.; Lucht, B. L. Thermal Decomposition of LiPF 6 -Based Electrolytes for Lithium-Ion Batteries. J. Electrochem. Soc. 2005, 152 (12), A2327-A2334. https://doi.org/10.1149/1.2083267.

(3) Fulmer, G. R.; Miller, A. J. M.; Sherden, N. H.; Gottlieb, H. E.; Nudelman, A.; Stoltz, B. M.; Bercaw, J. E.; Goldberg, K. I. NMR Chemical Shifts of Trace Impurities: Common Laboratory Solvents, Organics, and Gases in Deuterated Solvents Relevant to the Organometallic Chemist. Organometallics 2010, 29 (9), 2176-2179. https://doi.org/10.1021/om100106e.

(4) Shenderovich, I. G.; Smirnov, S. N.; Denisov, G. S.; Gindin, V. A.; Golubev, N. S.; Dunger, A.; Reibke, R.; Kirpekar, S.; Malkina, O. L.; Limbach, H. H. Nuclear Magnetic Resonance of Hydrogen Bonded Clusters B between F- and (HF)n: Experiment and Theory. Berichte der Bunsengesellschaft/Physical Chem. Chem. Phys. 1998, 102 (3), 422-428. https://doi.org/10.1002/bbpc.19981020322.

(5) Shenderovich, I. G.; Tolstoy, P. M.; Golubev, N. S.; Smirnov, S. N.; Denisov, G. S.; Limbach, H. $H$. Low-Temperature NMR Studies of the Structure and Dynamics of a Novel Series of AcidBase Complexes of HF with Collidine Exhibiting Scalar Couplings across Hydrogen Bonds. J. Am. Chem. Soc. 2003, 125 (38), 11710-11720. https://doi.org/10.1021/ja029183a.

(6) Zhuang, G. V.; Xu, K.; Yang, H.; Jow, T. R.; Ross, P. N. Lithium Ethylene Dicarbonate Identified as the Primary Product of Chemical and Electrochemical Reduction of EC in 1.2 M LiPF 6/EC:EMC Electrolyte. J. Phys. Chem. B 2005, 109 (37), 17567-17573. https://doi.org/10.1021/jp052474w.

(7) Xu, K.; Zhuang, G. V.; Allen, J. L.; Lee, U.; Zhang, S. S.; Ross, P. N.; Jow, T. R. Syntheses and Characterization of Lithium Alkyl Mono- and Bicarbonates as Components of Surface Films in Li-Ion Batteries. J. Phys. Chem. B 2006, 110 (15), 7708-7719. https://doi.org/10.1021/jp0601522.

(8) Sen, R.; Goeppert, A.; Kar, S.; Prakash, G. K. S. Hydroxide Based Integrated CO2 Capture from Air and Conversion to Methanol. J. Am. Chem. Soc. 2020, 142 (10), 4544-4549. https://doi.org/10.1021/jacs.9b12711.

(9) Kofron, W. G.; Wideman, L. G. Specific Synthesis and Selective Alkylation and Condensation of Monoesters of Substituted Succinic Acids. J. Org. Chem. 1972, 37 (4), 555-559. https://doi.org/10.1021/jo00969a006.

(10) Leskes, M.; Kim, G.; Liu, T.; Michan, A. L.; Aussenac, F.; Dorffer, P.; Paul, S.; Grey, C. P. SurfaceSensitive NMR Detection of the Solid Electrolyte Interphase Layer on Reduced Graphene Oxide. J. Phys. Chem. Lett. 2017, 8 (5), 1078-1085. https://doi.org/10.1021/acs.jpclett.6b02590.

(11) Nixon, J. F.; Schmutzler, R. Phosphorus-31 Nuclear Magnetic Resonance Studies of Phosphorus-Fluorine Compounds. Spectrochim. Acta 1964, 20 (12), 1835-1842. https://doi.org/10.1016/0371-1951(64)80187-9.

(12) Wiemers-Meyer, S.; Winter, M.; Nowak, S. Mechanistic Insights into Lithium Ion Battery Electrolyte Degradation - a Quantitative NMR Study. Phys. Chem. Chem. Phys. 2016, 18 (38), 26595-26601. https://doi.org/10.1039/C6CP05276B.

(13) Babij, N. R.; McCusker, E. O.; Whiteker, G. T.; Canturk, B.; Choy, N.; Creemer, L. C.; Amicis, C. V. D.; Hewlett, N. M.; Johnson, P. L.; Knobelsdorf, J. A.; et al. NMR Chemical Shifts of Trace Impurities: Industrially Preferred Solvents Used in Process and Green Chemistry. Org. Process Res. Dev. 2016, 20 (3), 661-667. https://doi.org/10.1021/acs.oprd.5b00417.

(14) Trincado, M.; Kühlein, K.; Grützmacher, H. Metal-Ligand Cooperation in the Catalytic 
Dehydrogenative Coupling (DHC) of Polyalcohols to Carboxylic Acid Derivatives. Chem. - A Eur. J. 2011, 17 (42), 11905-11913. https://doi.org/10.1002/chem.201101084.

(15) Rivlin, M.; Eliav, U.; Navon, G. NMR Studies of the Equilibria and Reaction Rates in Aqueous Solutions of Formaldehyde. J. Phys. Chem. B 2015, 119 (12), 4479-4487. https://doi.org/10.1021/jp513020y.

(16) Finney, W. F.; Wilson, E.; Callender, A.; Morris, M. D.; Beck, L. W. Reexamination of Hexafluorosilicate Hydrolysis by 19F NMR and PH Measurement. Environ. Sci. Technol. 2006, 40 (8), 2572-2577. https://doi.org/10.1021/es052295s.

(17) Parimalam, B. S.; Lucht, B. L. Reduction Reactions of Electrolyte Salts for Lithium Ion Batteries: LiPF6, LiBF4, LiDFOB, LiBOB, and LiTFSI. J. Electrochem. Soc. 2018, 165 (2), A251A255. https://doi.org/10.1149/2.0901802jes.

(18) Jin, Y.; Kneusels, N. J. H.; Magusin, P. C. M. M.; Kim, G.; Castillo-Martínez, E.; Marbella, L. E.; Kerber, R. N.; Howe, D. J.; Paul, S.; Liu, T.; et al. Identifying the Structural Basis for the Increased Stability of the Solid Electrolyte Interphase Formed on Silicon with the Additive Fluoroethylene Carbonate. J. Am. Chem. Soc. 2017, 139 (42), 14992-15004. https://doi.org/10.1021/jacs.7b06834.

(19) Xu, M.; Xiao, A.; Yang, L.; Lucht, B. Novel Electrolyte for Lithium lon Batteries: Lithum Tetrafluorooxalatophosphate (LiPF4C2O4). ECS Trans. 2009, 16 (35), 3-11. https://doi.org/10.1149/1.3123122. 